\title{
Kajian Dan Simulasi Prinsip Kerja Coded Orthogonal Frequency Division Multiplexing Untuk Sistem Transmisi Radio Over Fiber
}

\author{
Raissa Lynn ${ }^{1}$, Yohanes Calvinus ${ }^{1}$,
}

\begin{abstract}
The fiber optics communication system is so far known to offer the highest information bandwidth, and has been intensively deployed world wide. This superior technological merit is fundamentally related to its use of high frequency optical carrier. However, optical fiber communication system requires the installation of fiber optics cable for the optical data transmission. This implied its restricted applications to user at fixed positions. On the other hand, the open air cellular communication technology has offered the high mobility and flexibility for the users. The obvious benefit of combining the two systems has led to the development of new technology that integrates optical fiber communication system with wireless communication system to provide great communication mobility with wide bandwidth. The integrated system (hybrid system) is known as the Radio over Fiber (RoF) system. In RoF system, traffic congestion problems between mobile phones via the Base Station (BS) and Remote Antenna Unit (RAU) can be reduced. In this final project, RoF communication system within the LAN network is considered. The realization of this model employs the Orthogonal Frequency Division Multiplexing (OFDM) method, which is equipped with convolution code technique, multi- mode optical fiber, Quadrature Amplitude Modulation (QAM) technique for digital modulation technique. In addition to that, the model also adopt Intensity Modulation-Direct Detection (IM-DD) technique for electro optic - opto electric conversion process. The system performance is analyzed and evaluated on the bases of Bit Error Rate (BER) variation versus the optical fiber's transmission length for a selection of LD's and PIN photodetectors as well as different multimode optical fibers.
\end{abstract}

Keywords: RoF, OFDM, convolution code, multi mode optical fiber, QAM , IM-DD, BER

\begin{abstract}
ABSTRAK: Untuk memenuhi kebutuhan informasi pita lebar yang semakin tinggi, teknologi serat optik adalah solusi yang paling tepat. Keunggulan ini berkaitan dengan teknologi serat optik yang mempunyai gelombang pembawa berupa gelombang optik dengan frekuensi gelombang sangat tinggi dan lebar pita transmisi yang sangat besar. Namun, pada sisi lain operasi sistem komunikasi serat optik memerlukan tersedianya kabel serat optik dalam proses pengiriman informasi. Hal ini mengakibatkan mobilitas para pengguna menjadi terhambat. Keadaan ini mendorong perkembangan teknologi baru yang mengintegrasikan sistem komunikasi serat optik dengan sistem komunikasi nirkabel untuk memberikan mobilitas komunikasi yang besar. Sistem gabungan (sistem hibrida) ini adalah sistem Radio over Fiber (RoF). Dalam sistem RoF, lalu lintas (traffic) yang sangat padat antara handphone melalui Base Station (BS) dan Remote Antenna Unit (RAU) dapat disalurkan dengan hubungan serat optik. Dalam tugas akhir ini teknik Orthogonal Frquency Division Multiplexing (OFDM) yang dilengkapi dengan teknik pengkodeean kanal kode konvolusi, serat optik multi mode, teknik modulasi Quadrature Amplitude Modulation (QAM) dan teknik Intensity Modulation - Direct Detection (IM-DD) untuk proses konversi elektro optik - opto elektrik. Kinerja sistem ini diuji dan dianalisa berdasarkan karakteristik variasi Bit Error Rate (BER) terhadap jarak tempuh serat optik untuk sejumlah pilihan komponen/modul dalam sistem.
\end{abstract}

Kata kunci: RoF, OFDM, kode konvolusi, serat optik multi mode, QAM, IM-DD, BER.

\section{PENDAHULUAN}

$\mathrm{D}$ ewasa ini kebutuhan akan akses dan pertukaran informasi sudah tak dapat dielakkan oleh masyarakat dalam hampir semua aspek kegiatannya. Dalam era informasi, akses informasi menjadi sangat penting untuk mendukung banyak kegiatan masyarakat dalam proses pengambilan keputusan, perencanaan kegiatan, dan pekerjaan profesi maupun pengurusan rumah tangganya, termasuk hubungan sosial yang tak terpisah dalam kehidupannya sehari-hari. Informasi yang lengkap pada umumnya membutuhkan layanan sistem transmisi berpita lebar (broadband) untuk menunjang kadar dan kualitas aliran informasi antara pelanggan dan kebutuhan pelanggan akan akses informasi yang tersedia di internet.

Teknologi yang paling tepat untuk memenuhi kebutuhan transmisi informasi pita lebar adalah teknologi serat optik. Keunggulan ini berkaitan dengan teknologi serat optik yang beroperasi dengan gelombang pembawa berupa gelombang optik yang memiliki frekuensi gelombang sangat tinggi. Tetapi pada sisi lain operasi sistem komunikasi serat optik memerlukan cara transmisi melalui serat optik, dan karena itu mempunyai kendala dari keterbatasan penggunaannya oleh tersedianya kabel serat optik yang terpasang. Karena itu, komunikasi hanya dapat dilakukan antara terminal tertentu yang memiliki hubungan serat optik. Ini berarti pelayanan kepada para pengguna yang memerlukan mobilitas tinggi seperti yang tersedia oleh handphone tidak dapat dipenuhi oleh sistem komunikasi serat optik saja.

Agar dapat memenuhi kebutuhan pita transmisi serat optik yang lebar dan mobilitas telepon seluler pemakai, telah dikembangkan cara yang memungkinkan hubungan transmisi dengan mengintegrasikan sistem komunikasi nirkabel (gelombang radio) dengan sistem komunikasi serat optik. Untuk keperluan ini telah dikaji oleh para ahli dan dihasilkan sejumlah konsep serta teknik yang secara umum disebut teknologi Radio over Fiber (RoF). RoF adalah sebuah teknologi yang memungkinkan sinyal Radio Frekuensi (RF) dimodulasi ke gelombang pembawa optik untuk dikirim selanjutnya melalui serat optik. Teknologi RoF biasanya diimplementasikan pada suatu sistem komunikasi wireless untuk mentransmisikan sinyal RF melalui serat optik dari Base Station menuju Remote Antenna Unit (RAU)[1]. Realisasi teknologi RoF ini memerlukan antara lain, adanya teknik Frequency Division Multiplexing (FDM), khususnya Coded Orthogonal Frequency Division Multiplexing (COFDM). COFDM merupakan sistem OFDM yang menggunakan pengkodean kanal (Channel Coding / Error Correction Coding) [1]. Ide utama dari COFDM adalah mengkodekan sinyal masukan berupa gambar, suara, dan teks untuk

${ }^{1}$ Program Studi Teknik Elektro, Fakultas Teknik Universitas Tarumanagara 
dibagi ke dalam kanal frekuensi gelombang pembawa yang terpisah atau yang berbeda frekuensi dan saling orthogonal agar tidak terjadi interferensi yang tidak diinginkan. Kemudian semua saluran frekuensi tersebut diolah dengan proses multiplexing (OFDM) untuk diteruskan ke dalam serat optik [1].

Untuk persiapan tugas akhir ini penulis melakukan survei ke dua gedung di Jakarta yaitu SCTV Tower Senayan City dan Kampus I Universitas Tarumanagara. Hasil survei menunjukkan bahwa kedua gedung tersebut belum menggunakan teknologi ROF dalam jaringan Local Area Network (LAN) yang tersedia. Selain survei di lapangan, juga telah dilakukan survei literatur dan kajian awalnya meliputi artikel-artikel sebagai berikut :

1. A. M. Matarneh, Y. A. Al-Sbou, New Investigation of Image Transmission using Radio over Fiber. Trends Applied Sci. Res, 7(9): 758 - 767, 2012.

2. A. M. J. Koonen, M. G. Larrode, A. Ng'oma, K. Wang, H. Yang, Y. Zheng, E. Tangdiongga, Perspectives of Radio over Fiber Technologies. Optical Society of America, 2008.

3. M. Shikha, N. Kumar, COFDM for Radio over Multimode Fiber: a Review, IJCA special issues on IP Multimedia Communications, pp. 22-28, 2011.

4. R. Prasad, OFDM for Wireless Communication Systems, Artech House universal personal communications series, 2004.

Hasil dari kajian awal seluruh artikel-artikel tersebut telah diperoleh informasi bahwa dengan sistem RoF, laju data, kapasitas data, dan efisiensi spektrum dapat ditingkatkan tanpa mengganggu kemampuan mobilitas dari pengguna.

Program simulasi yang dirancang dan disusun adalah program yang dapat menjelaskan prinsip kerja dari sistem Radio Over Fiber termasuk cara operasi dari modul-modul yang berfungsi pengkodean, mapping, interleaver, OFDM modulator, dan tampilan input yang dapat divariasi, serta tampilan hasil transmisi yang dilengkapi dengan performanya.

Berdasarkan hasil survei di lapangan dan survei literatur tentang sistem yang ada, penulis membuat tabel perbandingan yang dapat dilihat pada tabel 1 .

- Tabel 1. Perbandingan hasil survei dengan sistem yang dirancang

\begin{tabular}{|c|c|c|c|}
\hline No & $\begin{array}{c}\text { Sistem Komunikasi Nirkabel } \\
\text { dalam Jaringan LAN } \\
\text { (Kampus Untar 1) }\end{array}$ & $\begin{array}{c}\text { Sistem Komunikasi Fiber } \\
\text { Optik dalam Jaringan LAN } \\
\text { (SCTV Tower) }\end{array}$ & $\begin{array}{c}\text { Sistem Komunikasi Radio } \\
\text { over Fiber dalam Jaringan } \\
\text { LAN }\end{array}$ \\
\hline 1 & $\begin{array}{c}\text { Kadar informasi yang } \\
\text { disalurkan rendah }\end{array}$ & $\begin{array}{c}\text { Kadar informasi yang } \\
\text { disalurkan besar (broadband) }\end{array}$ & $\begin{array}{c}\text { Kadar informasi yang disalurkan } \\
\text { besar (broadband) }\end{array}$ \\
\hline 2 & $\begin{array}{c}\text { Terminal pengirim dan } \\
\text { penerima bersifat fleksibel } \\
\text { (mobile) }\end{array}$ & $\begin{array}{c}\text { Terminal pengirim dan } \\
\text { penerima tidak mobile (statis) }\end{array}$ & $\begin{array}{c}\text { Terminal pengirim dan penerima } \\
\text { bersifat fleksibel (mobile) }\end{array}$ \\
\hline 3 & $\begin{array}{c}\text { Mempunyai laju data yang } \\
\text { rendah }\end{array}$ & $\begin{array}{c}\text { Mempunyai laju data yang } \\
\text { tinggi }\end{array}$ & $\begin{array}{c}\text { Mempunyai laju data yang } \\
\text { tinggi }\end{array}$ \\
\hline
\end{tabular}

\section{KAJIAN PUSTAKA}

Sistem komunikasi Radio over Fiber $(R o F)$ adalah sistem komunikasi yang menggabungkan manfaat mobilitas hand phone/selular dan pita transmisi lebar dari serat optik dalam suatu sistem hibrid. Keunggulan dari sistem komunikasi RoF antara lain : mempunyai atenuasi yang rendah dan lebar pita yang besar, tahan terhadap efek interferensi elektromagnetik (electromagnetic interference; EMI), instalasi dan perawatannya mudah.

Dalam sistem ini informasi digital dengan gelombang pembawa berfrekuensi radio (RF) pada central site (CS) diolah secara berurut dengan proses pengkodean, multipleksing, dan modulasi. Hasil olahan sinyal RF tersebut dialihkan menjadi sinyal optik dengan konverter elektro-optik (E/O) dan dikirimkan kepada Remote Site (RS) melalui serat optik. Pada RS sinyal optik akan dialihkan kembali menjadi sinyal RF dengan konverter O/E kemudian dipancarkan oleh antena kepada para pengguna layanan wireless. Secara garis besar pola operasi sistem ini dijelaskan dalam Gambar 1. 


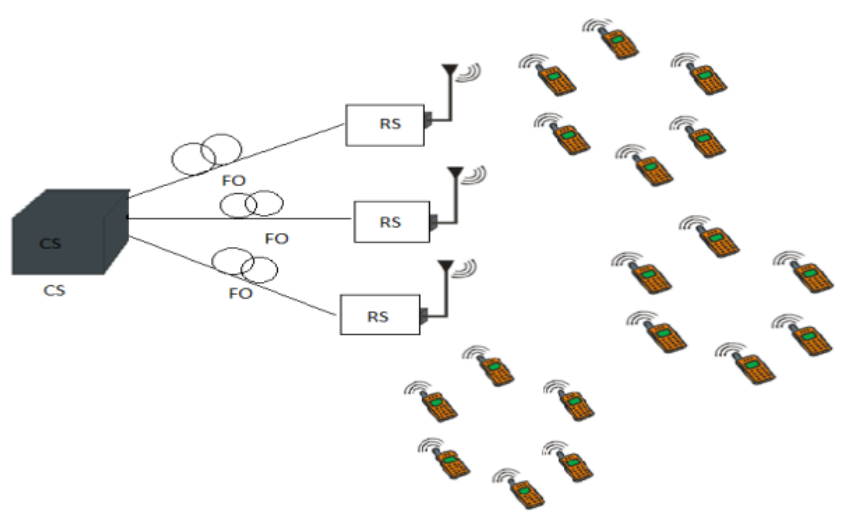

- Gambar 1. Ilustrasi sistem komunikasi RoF

Jika area aplikasi sistem komunikasi RoF adalah sebuah jaringan GSM, maka yang bertindak sebagai CS dan RS masing-masing adalah mobile switching centre (MSC) dan base station (BS). Sedangkan untuk area aplikasi jaringan WLAN, yang bertindak sebagai CS dan RS adalah head end dan radio access point (RAP).

Secara garis besar sistem RoF yang dirancang dapat dibagi menjadi tiga subsistem yaitu subsistem pemancar (transmitter), subsistem sambungan optik (optical link), dan subsistem penerima (receiver). Subsistem pemancar tersebut dilengkapi dengan perangkat OFDM , pengkodean (COFDM), konverter E/O. Untuk subsistem sambungan optiknya digunakan serat optik bermodus jamak (Multimode; MM) , dan subsistem penerima dilengkapi konverter O/E.

Dalam simulasi yang dihasilkan ini akan dipertunjukkan proses sinyal berkadar tinggi yang terhimpun dan dikirimkan melalui suatu serat optik dengan pita transmisi yang lebar kepada sejumlah pelanggan pelayanan nirkabel dengan performa (Bit Error Rate; BER) yang layak.

\section{Diagram Blok}

Diagram blok dari simulasi rangkaian proses pengolahan dan transmisi RoF yang disusun dapat dilihat dalam Gambar 2.

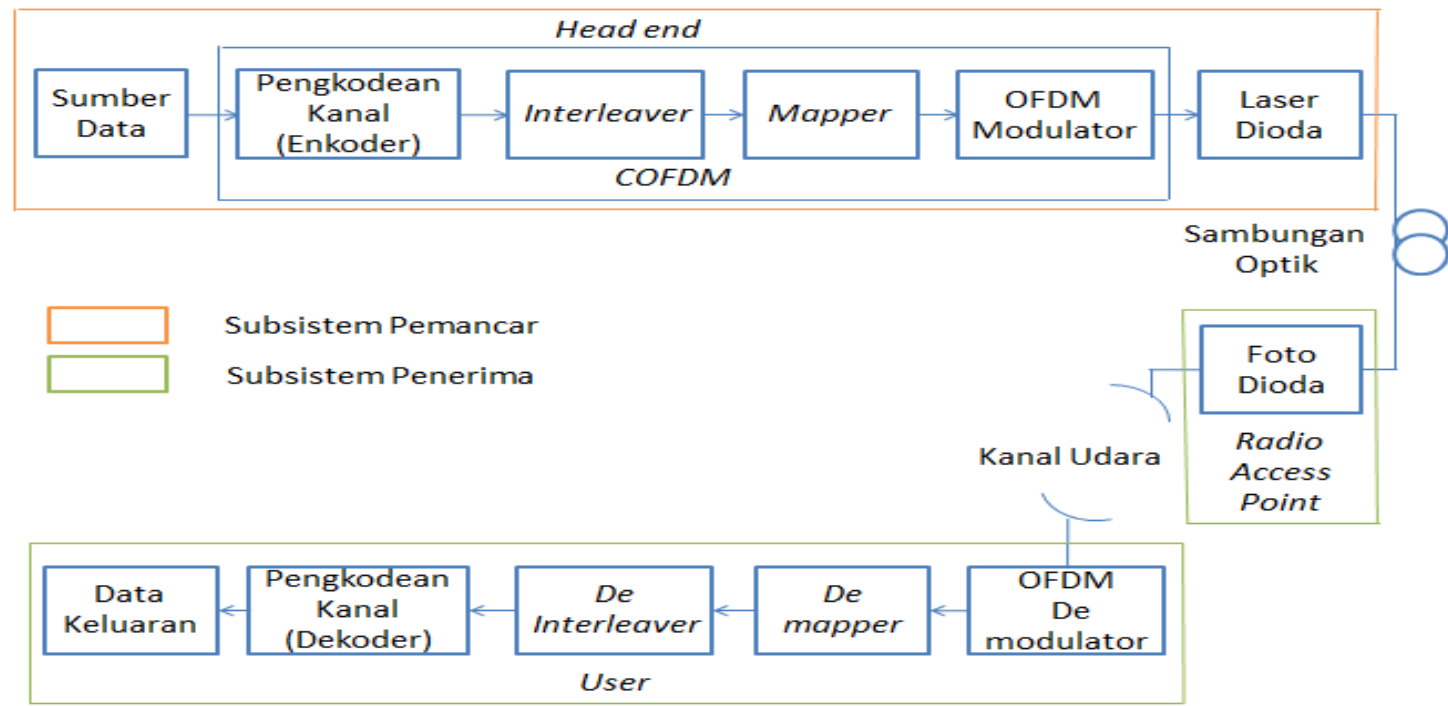

- Gambar 2. Diagram blok dari sistem COFDM-RoF

\section{Pengkodean Kanal (Channel Coding)}

Pengkodean kanal merupakan proses pengkodean yang berfungsi melindungi data digital dari gangguan derau yang terjadi sepanjang kanal transmisi dan media penyimpanan. Caranya adalah memberikan bit tambahan (redundant bit) pada data yang akan ditransmisikan. Bit-bit tambahan tersebut digunakan oleh decoder pada penerima untuk mengurangi gangguan (error) dan mengembalikan data yang ditransmisikan ke bentuk aslinya. Kode tambahan tersebut terdiri dari kode deteksi gangguan (error detection code) dan kode koreksi gangguan (error correction codes).

Pengkodean kanal dapat dibagi dalam dua kategori yaitu kode blok (block codes) dan kode konvolusi (convolutional codes). 


\section{Kode Konvolusi}

Pada kode konvolusi, code sequence ( $\mathrm{n}$ bit) yang dihasilkan oleh enkoder tidak hanya bergantung pada $\mathrm{k}$ bit informasi, tetapi juga pada m data digit sebelumnya (memori). Oleh karena itu, kode konvolusi umumnya mempunyai tiga parameter berikut :

- $\mathrm{n}=$ jumlah bit keluaran

- $\mathrm{k}=$ jumlah bit masukan

- $\mathrm{m}=$ jumlah dari shift register (jumlah memori)

Implementasi dari enkoder kode konvolusi terdiri dari beberapa shift register dan adder modulo 2. Relasi antar shift register dan adder modulo 2 direalisasikan menggunakan generator polinomial untuk menghasilkan codeword.

\section{Matrix Interleaver}

Matrix interleaver merupakan salah satu jenis blok interleaver yang mempunyai cara kerja mengambil simbol yang telah dikodekan dan menuliskannya ke dalam kolom-kolom pada sebuah matriks dengan $\mathrm{N}$ baris dan B kolom. Permutasi dilakukan dengan membaca simbol-simbol tersebut baris per baris sebelum transmisi dilakukan.

\section{M-ary Quadrature Amplitude Modulation (M-ary QAM)}

M-ary QAM adalah teknik modulasi digital yang merupakan gabungan dari phase shift keying dan amplitude shift keying. Konstelasi dari M-ary QAM, khususnya untuk nilai M di atas empat, menunjukkan bahwa sinyal dan fasa dari masing-masing simbol mempunyai nilai yang berbeda-beda. Konstelasi dari M-ary QAM pada umumnya berbentuk persegi. Gambaran bentuk umum dari sinyal M-ary QAM (16-QAM) dapat dilihat dalam Gambar 3.

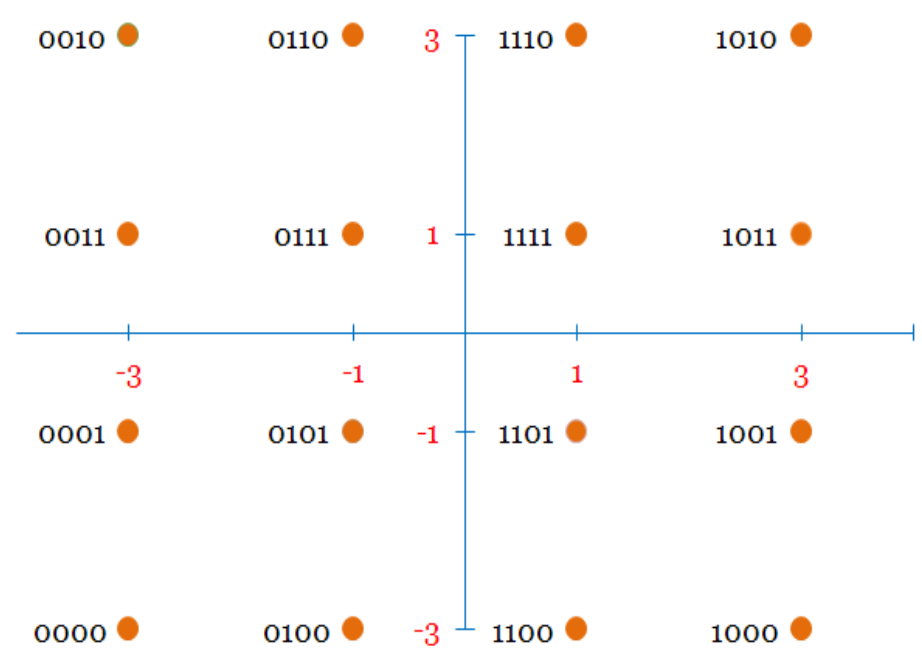

- Gambar 3. Diagram konstelasi 16 QAM

\section{Orthogonal Frequency Division Multiplexing (OFDM)}

OFDM adalah pengembangan dari teknik FDM konvensional. Teknik OFDM membagi lebar pita yang tersedia menjadi beberapa subcarrier pada domain frekuensi (multicarrier). Masing-masing subcarrier bersifat bebas satu dari lainnya (ortogonal). Bila seluruh subcarrier tersebut memenuhi syarat ortogonalitas, maka spektrumnya dapat saling tumpang tindih tanpa menimbulkan gangguan interferensi, sehingga kadar spektralnya tinggi. Ortogonalitas untuk sepasang subcarrier dapat dirumuskan sebagai berikut[2] :

$$
\int_{-T / 2}^{T / 2} \cos \left(\frac{2 \pi n t}{T}\right) \cos \left(\frac{2 \pi m t}{T}\right) d t \quad=\quad 0 \quad, \quad m \quad \neq
$$

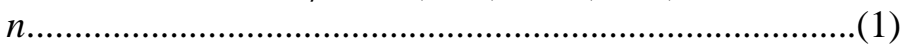

Ortogonalitas dari sinyal OFDM dalam domain waktu dan frekuensi diilustrasikan secara sederhana dalam Gambar 4. 


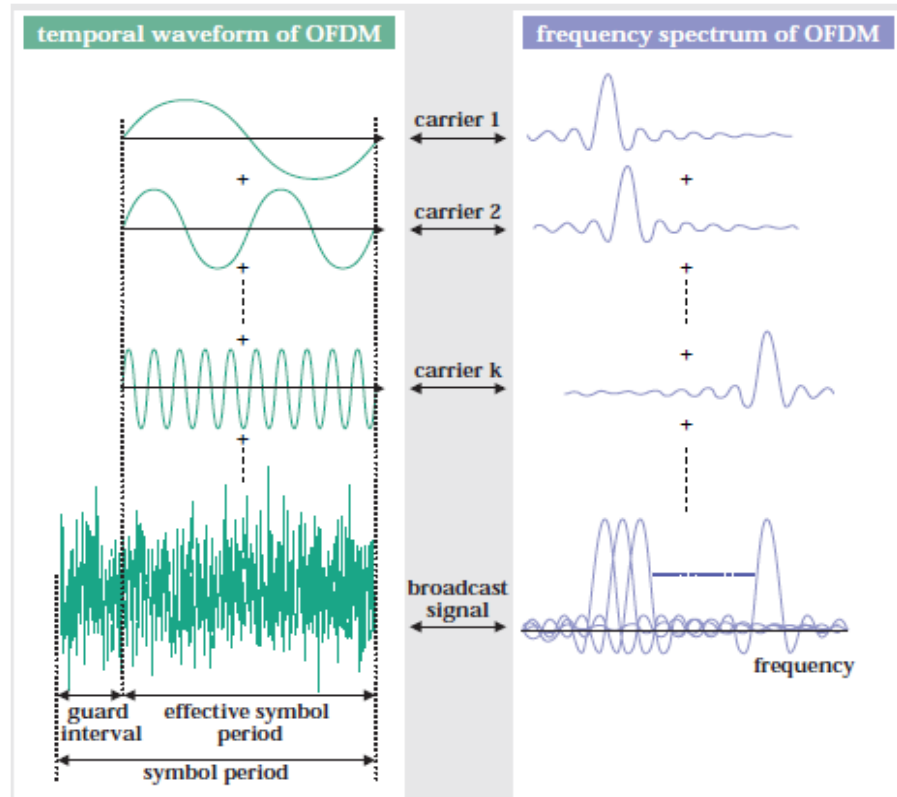

- Gambar 4. Sinyal OFDM dalam domain waktu dan frekuensi [3]

Untuk menghasilkan ortogonalitas antar subcarrier, digunakan algoritma Fast Fourier Transform (FFT). Secara umum, sinyal OFDM dapat direpresentasikan sebagai [4]: Sinyal
OFDM
$=$
$c(t)$

$\sum_{n=0}^{N-1} \operatorname{Sn}(t) \sin (2 \pi(f n) t)$

$S n(t)=$ simbol yang sudah dipetakan pada konstelasi tertentu

$f n \quad=$ ortogonal frekuensi

Suatu sistem OFDM umumnya didefinisikan oleh: panjang IFFT/FFT (N) yang merepresentasikan banyaknya sub-carrier yang ada (N), teknik modulasi yang digunakan (PSK atau QAM), dan laju data[4]. Sistem OFDM yang dilengkapi dengan pengkodean kanal disebut sebagai sistem Coded Orthogonal Frequency Division Multiplexing (COFDM).

\section{Intensity Modulation - Direct Detection (IM-DD)}

Prinsip kerja dari teknik IM-DD adalah memodulasi intensitas dari sumber cahaya dengan sinyal RF kemudian menggunakan Photo Detector (PD) untuk deteksi langsung dan mengkonversi sinyal optik menjadi sinyal RF.

Terdapat dua cara untuk memodulasi sumber cahaya. Pertama, dioda laser secara langsung dimodulasi oleh sinyal RF yang mengatur arus bias dari laser (Directly Modulated Laser). Cara kedua adalah mengoperasikan laser pada mode gelombang kontinu (Continuous Wave mode) kemudian menggunakan modulator eksternal seperti Mach Zehnder Modulator (MZM) untuk memodulasi intensitas dari cahaya. Ilustrasi dari kedua teknik tersebut dapat dilihat dalam Gambar 5.

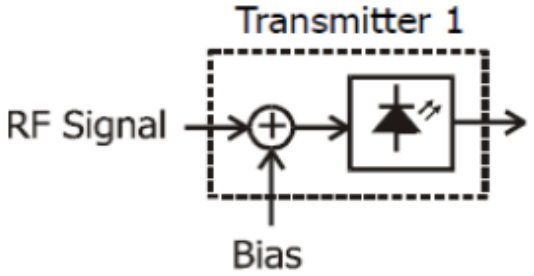

(a)

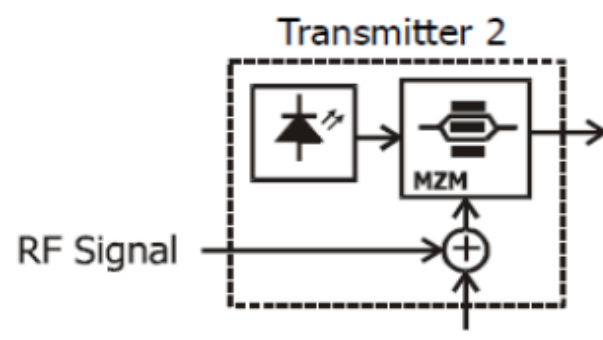

Bias

(b)

- Gambar 5. Modulasi Sinyal RF dengan modulasi langsung (a) dengan laser (b) dengan modulator eksternal

\section{Algoritma Viterbi}

Pada sistem komunikasi digital modern, algoritma viterbi untuk proses decoding kode konvolusi merupakan sebuah teknik yang efisien dan optimum. Algoritma viterbi memilih sebuah jalur (path) melalui kode trellis untuk menghasilkan sebuah codeword yang mempunyai perbedaan paling sedikit dengan codeword yang diterima pada proses decoding kode konvolusi. Algoritma Viterbi mencari semua jalur yang mungkin untuk 
menghitung metrik dari jalur (path metrics). Setiap state (node) pada diagram trellis diberi sebuah nilai tertentu dari state $(\mathrm{s})=0$ pada waktu $\mathrm{t}=0$ sampai $\mathrm{s}=\mathrm{K}$ tertentu saat $\mathrm{t} \geq 0$. Pada setiap state, jalur dengan metrik terbaik disebut survivor. Setiap jalur yang dipilih oleh algoritma Viterbi adalah jalur dengan kebolehjadian maksimum (maximum likelihood)

\section{REALISASI RANCANGAN}

Untuk realisasi simulasi sistem COFDM-RoF ini digunakan software Matlab \& Simulink R2008a. Selanjutnya dalam pasal-pasal berikut akan dijelaskan teknik yang digunakan dalam proses realisasi masing-masing modul (seperti yang terdapat dalam Gambar 2).

\section{Modul Enkoder-Dekoder}

Untuk modul enkoder, teknik pengkodean yang dipilih adalah kode konvolusi. Kode konvolusi memberikan coding gain pada laju coding yang berbeda-beda sesuai dengan kebutuhan pemakai saluran informasi. Dalam simulasi ini, enkoder kode konvolusi yang digunakan mempunya: dengan generator polinomial [001111001], [001011011]. Gambar 6 m konvolusi yang digunakan dalam simulasi.

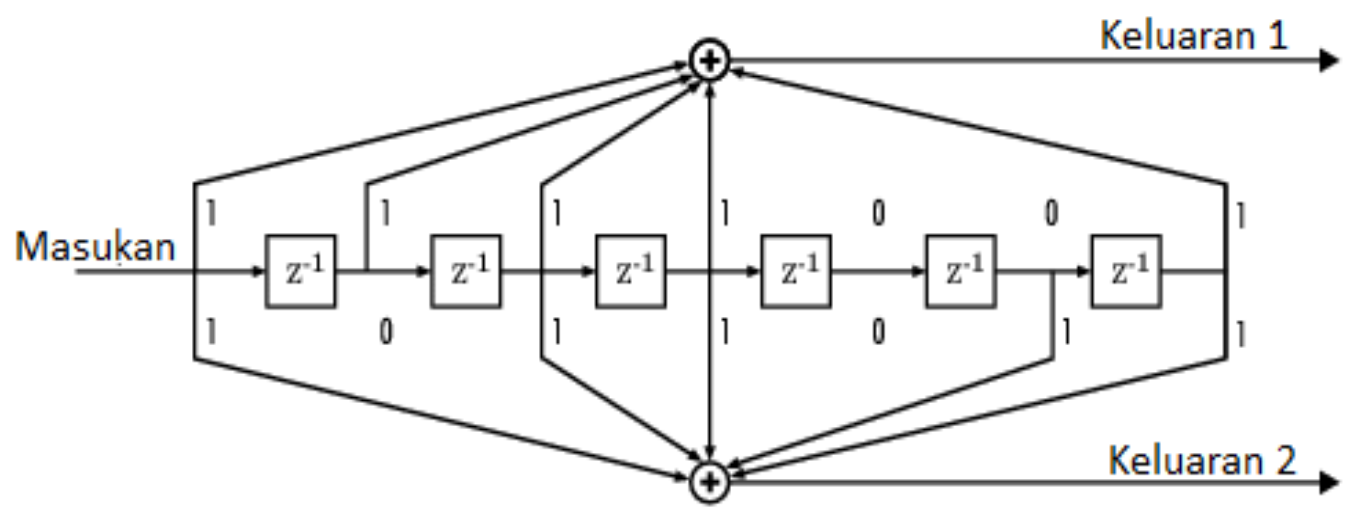

- Gambar 6. Ilustrasi enkoder kode konvolusi dalam simulasi

Untuk enkoder kode konvolusi dengan laju kode $\geq 1 / 2$, matriks puncture yang digunakan adalah 1101 untuk laju kode 2/3, 111001 untuk laju kode 3/4, dan 1101100110 untuk laju kode 5/6.

Dalam proses decoding pada penerima, teknik yang digunakan adalah algoritma viterbi hard decision. Algoritma ini mempunyai cara kerja yang sederhana dan umum digunakan untuk proses decoding kode konvolusi.

Untuk realisasi modul enkoder-dekoder dalam simulasi digunakan modul convolutional encoder viterbi decoder yang tersedia dalam software Simulink.

\section{Modul Interleaver - Deinterleaver}

Teknik interleaver yang dipilih adalah matriks interleaver. Matriks deinterleaver bertugas melakukan proses kebalikan dari matriks interleaver. Teknik ini mempunyai cara kerja yang sederhana dan dapat meminimalisir efek burst error yang terjadi saat proses transmisi. Ukuran matriks interleaver yang digunakan adalah 192 (16x12). Simulasi ini menggunakan modul matriks interleaver dan matriks deinterleaver yang tersedia dalam software Simulink.

\section{Modul Mapper-Demapper}

Modul mapper-demapper yang digunakan adalah 16 QAM dengan peta konstelasi berbentuk persegi. Pada teknik ini gelombang pembawa mengalami perubahan fasa maupun amplitudo sehingga mengurangi efek Inter Symbol Interference (ISI) dan menghemat penggunaan lebar pita. Dalam simulasi ini, digunakan modul Rectangular 16 QAM yang tersedia dalam software Simulink.

\section{Modul OFDM}

Teknik OFDM dipilih sebagai teknik multipleksing yang digunakan karena OFDM mempunyai banyak keunggulan antara lain, tahan terhadap efek ISI, ICI, multipath fading, serta mampu mengefisienkan lebar pita yang ada untuk membawa kadar informasi yang besar melalui sifat ortogonalnya. Parameter-parameter OFDM yang digunakan dalam simulasi ini mengikuti standar IEEE $802.11 \mathrm{~g}$ seperti yang terlihat dalam Tabel 2. 
Tabel 2. Parameter OFDM

\begin{tabular}{|c|c|}
\hline OFDM simbol duration & $4 \mu \mathrm{s}$ \\
\hline FFT size & 64 \\
\hline Carrier frequency & $2.4 \mathrm{GHz}$ \\
\hline Subcarrier spacing & $312.5 \mathrm{kHz}$ \\
\hline Number of data subcarriers & 52 \\
\hline Number of pilots & 4 \\
\hline Guard Interval & $800 \mathrm{~ns}$ \\
\hline
\end{tabular}

Untuk realisasi modul OFDM digunakan modul OFDM yang tersedia dalam software Simulink.

\section{Modul Modulator Optik (Konversi Elektro-Optik)}

Dalam simulasi ini teknik modulasi optik yang digunakan adalah modulasi laser secara langsung (Direct Modulated Laser). Teknik ini merupakan cara yang paling sederhana untuk modulasi optik serta memerlukan biaya yang murah karena proses modulasinya hanya memerlukan laser dioda saja, sehingga cocok untuk digunakan pada sistem RoF di dalam gedung. Rumus yang digunakan untuk modulasi laser secara langsung adalah :

$$
\mathrm{P}_{\mathrm{opt}}=\eta \cdot\left\{\mathrm{I}(\mathrm{t})-\mathrm{I}_{\mathrm{th}}\right\}
$$

$\mathrm{I}(\mathrm{t})$ = besarnya arus sinyal informasi ditambah dengan arus bias (Ampere)

$\eta \quad=$ slope efficiency dari Laser Diode (LD) yang digunakan (Watt/Ampere)

Tipe laser yang digunakan adalah VCSEL (Vertical Cavity Surface Emitting Laser) untuk transmisi pada panjang gelombang $850 \mathrm{~nm}$. Parameter dari LD yang digunakan dapat dilihat pada Tabel 3.

- Tabel 3. Parameter LD

\begin{tabular}{|c|c|c|c|}
\hline LD (VCSEL) & LD 1 & LD2 & LD3 \\
\hline Parameter & & & \\
\hline$\lambda$ & $850 \mathrm{~nm}$ & $850 \mathrm{~nm}$ & $850 \mathrm{~nm}$ \\
\hline$\Delta \lambda$ & $0.5 \mathrm{~nm}$ & $0.85 \mathrm{~nm}$ & $1 \mathrm{~nm}$ \\
\hline Ith & $2 \mathrm{~mA}$ & $5 \mathrm{~mA}$ & $3.5 \mathrm{~mA}$ \\
\hline Ibias & $6 \mathrm{~mA}$ & $20 \mathrm{~mA}$ & $7.5 \mathrm{~mA}$ \\
\hline$\eta$ & $0.1 \mathrm{~W} / \mathrm{A}$ & $0.4 \mathrm{~W} / \mathrm{A}$ & $0.04 \mathrm{~W} / \mathrm{A}$ \\
\hline
\end{tabular}

\section{Modul Sambungan Optik}

Serat optik yang digunakan adalah serat optik multimode (MMF). MMF dipilih karena simulasi yang dilakukan bertujuan untuk sistem komunikasi WLAN di dalam gedung yang mempunyai jarak pendek. Untuk jarak pendek dan penggunaan dalam gedung, MMF mempunyai keunggulan dibanding SMF yaitu diameter MMF yang besar membuatnya lebih tahan terhadap efek bending loss dan mempunyai biaya pemeliharaan yang kecil. Jenis MMF yang digunakan adalah MMF graded index, karena efek dispersi intermodalnya lebih kecil dibandingkan MMF step index. Jendela transmisi yang digunakan pada sistem komunikasi optik dalam simulasi ini adalah jendela pertama $(850 \mathrm{~nm})$.

Dalam simulasi ini, efek atenuasi dari serat optik dan efek persambungan antar serat (splicing loss) diabaikan mengingat penggunaan serat optik yang berjarak pendek $(<1 \mathrm{~km})$. Efek dispersi yang diperhitungkan dalam serat optik MMF yang digunakan adalah dispersi kromatik dan dispersi intermodal.

Berikut adalah fungsi transfer (transfer function) yang digunakan untuk realisasi modul serat optik MMF [5] :

$e^{-\frac{1}{2} C_{G}^{2}(\widehat{\lambda}) x^{2}}$

$$
H_{G}(x, \hat{\lambda})=
$$

Dalam rumus di atas $\mathrm{C}_{\mathrm{G}}(\bar{\lambda})$ adalah gaussian link dispersion dan merupakan gabungan dari dispersi kromatik dan modal yang dapat dinyatakan dalam parameter dispersi bersangkutan sebagai berikut :

$$
C_{G}(\bar{\lambda})=
$$

$2 \pi \widehat{\sigma_{G}}(\bar{\lambda})$

$$
\widehat{\sigma_{G}}(\bar{\lambda})=
$$

$\sqrt{\sigma_{m}^{2}+\sigma_{c}^{2}}$

Selanjutnya $\sigma_{\mathrm{m}}$ dan $\sigma_{\mathrm{c}}$ masing-masing ditentukan oleh : 


$$
\sigma_{m}\left(z, \lambda_{c}\right)=\frac{z}{\pi} \sqrt{\frac{\ln 2}{2}} \frac{1}{\widehat{B W}\left(\lambda_{c}\right)} \cong 0.187 \frac{z}{\widehat{B W}\left(\lambda_{c}\right)}
$$

(ps).

$$
\sigma_{c}(z, \bar{\lambda})=\left|D_{c}(\bar{\lambda})\right| \sigma_{s} z
$$

(8) dengan,

$$
\begin{aligned}
& \sigma_{\mathrm{m}} \quad=\text { Dispersi intermodal }(\mathrm{ps}) \\
& \sigma_{\mathrm{c}} \quad=\text { Dispersi } \operatorname{kromatik}(\mathrm{ps}) \\
& \widehat{B W} \quad=\text { modal bandwidth dari serat optik (Mhz.km) } \\
& \mathrm{z} \quad=\text { panjang serat optik }(\mathrm{m}) \\
& \mathrm{f} \quad=\text { frekuensi }(\mathrm{GHz}) \\
& D_{C}(\bar{\lambda}) \quad=\text { koefisien dispersi kromatik }(\mathrm{ps} / \mathrm{nm} . \mathrm{km})
\end{aligned}
$$

Parameter dari serat optik MMF yang digunakan dapat dilihat pada Tabel 4.

- Tabel 4. Parameter serat optik MMF yang digunakan

\begin{tabular}{|c|c|c|c|}
\hline & MMF OM1 & MMF OM2 & MMF OM3 \\
\hline 2a (diameter fiber) & $62.5 \mu \mathrm{m}$ & $50 \mu \mathrm{m}$ & $50 \mu \mathrm{m}$ \\
\hline$\widehat{B W}$ & $200 \mathrm{MHz} . \mathrm{km}$ & $500 \mathrm{MHz} . \mathrm{km}$ & $1500 \mathrm{MHz} . \mathrm{km}$ \\
\hline$\lambda$ & $850 \mathrm{~nm}$ & $850 \mathrm{~nm}$ & $850 \mathrm{~nm}$ \\
\hline$|\mathrm{Dc}|$ & $110.5 \mathrm{ps} / \mathrm{nm} . \mathrm{km}$ & $95.97 \mathrm{ps} / \mathrm{nm} . \mathrm{km}$ & $95.97 \mathrm{ps} / \mathrm{nm} . \mathrm{km}$ \\
\hline
\end{tabular}

\section{Modul Foto Detektor (Konversi elektro-optik)}

Foto detektor (dioda foto) mendeteksi sinyal optik yang dikirim oleh laser melalui serat optik MMF dan melakukan proses konversi opto-elektrik berdasarkan hubungan antara arus listrik I, responsivitas (responsivity) dari foto dioda $(\mathrm{A} / \mathrm{W})$ serta daya optik $\left(\mathrm{P}_{\text {opt }}\right.$ dalam watt).

Dioda foto yang digunakan dalam simulasi ini adalah $p$-i-n photodiode dengan responsivitas sebesar $0.2 \mathrm{~A} / \mathrm{W}$. Dioda foto $\mathrm{p}-\mathrm{i}-\mathrm{n}$ dipilih karena strukturnya sederhana dan memiliki karakteristik operasional yang cukup memadai.

\section{Kanal Nirkabel (Wireless Channel)}

Dalam simulasi ini, kanal nirkabel dimodelkan menggunakan blok Additive White Gaussian Noise (AWGN) yang tersedia pada Simulink. Dalam sistem komunikasi digital, kanal AWGN adalah pemodelan kanal yang paling mudah untuk dianalisa. Model kanal AWGN mengasumsikan sumber distorsi hanya berasal dari penambahan white gaussian noise. White gaussian noise adalah model dari derau termal (thermal noise) yang dihasilkan oleh pergerakan elektron secara random pada penerima. Pada kanal AWGN, sinyal yang diterima mempunyai bentuk :

$$
R(t)=S(t)+
$$

$N(t)$.

dengan

$$
\begin{aligned}
& \mathrm{R}(\mathrm{t})=\text { sinyal yang diterima } \\
& \mathrm{S}(\mathrm{t})=\text { sinyal yang ditransmisikan } \\
& \mathrm{N}(\mathrm{t})=\text { White } \text { noise }
\end{aligned}
$$

Pada kanal AWGN, distorsi amplitudo yang terjadi akibat derau mempunyai distribusi normal (Gauss).

\section{HASIL PENGUJIAN}

Sistem COFDM-RoF yang dibangun secara kesuluruhan dapat dipandang sebagai gabungan dari dua subsistem utama, yaitu subsistem COFDM dan subsistem optik. Oleh karena itu, pengujian dilakukan dalam dua tahap. Tahap pertama adalah pengujian masing-masing subsistem tersebut, sedangkan tahap kedua adalah pengujian seluruh sistem secara terpadu (integrasi sistem). Gambar 7 memperlihatkan sistem COFDM-RoF secara rinci beserta pembagiannya sesuai dengan keperluan pengujian yang dimaksudkan di atas pada sejumlah titik yang ditandai dalam gambar tersebut. 


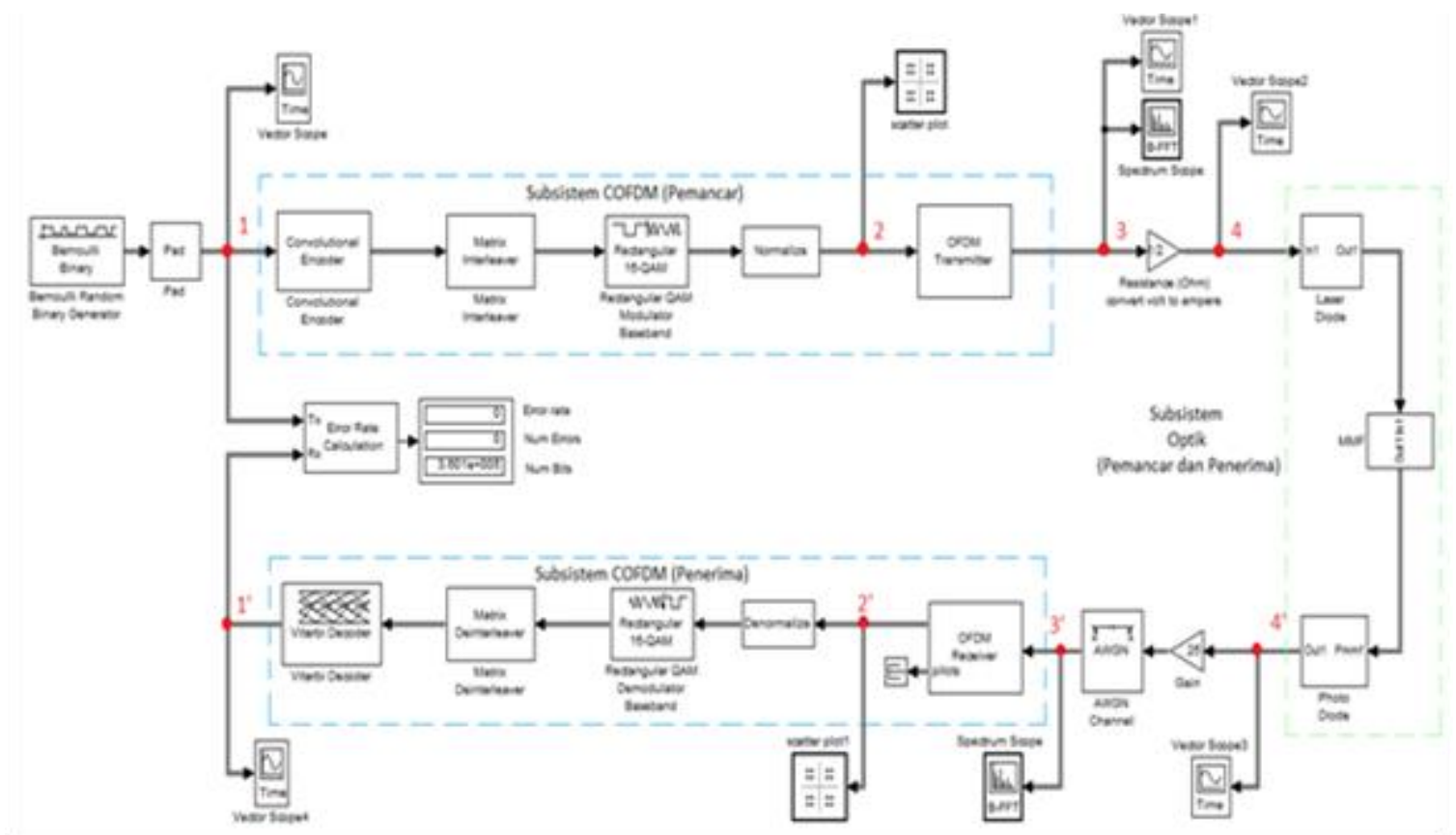

- Gambar 7. Sistem COFDM-RoF dan subsistemnya dalam Simulink

\section{Hasil Pengujian Subsistem COFDM (Pemancar)}

Pengujian subsistem COFDM pada pemancar dimulai dari perekaman pada titik uji 1, sinyal masukan berupa susunan digit biner seperti contoh yang terlihat dalam Gambar 8 .

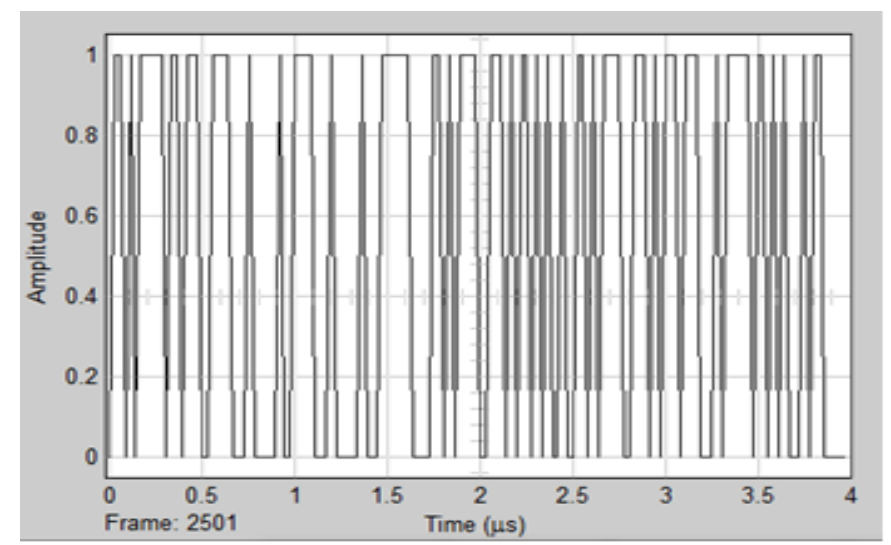

- Gambar 8. Sinyal masukan berupa digit biner yang terekam pada titik uji 1 dalam Gambar 7

Hasil pengujian subsistem pemancar yang diperoleh sebagai keluaran dari modul 16 QAM pada titik uji 2, berupa peta konstelasi yang ditampilkan dalam Gambar 9. Hasil ini sesuai dengan acuan dari program yang digunakan.

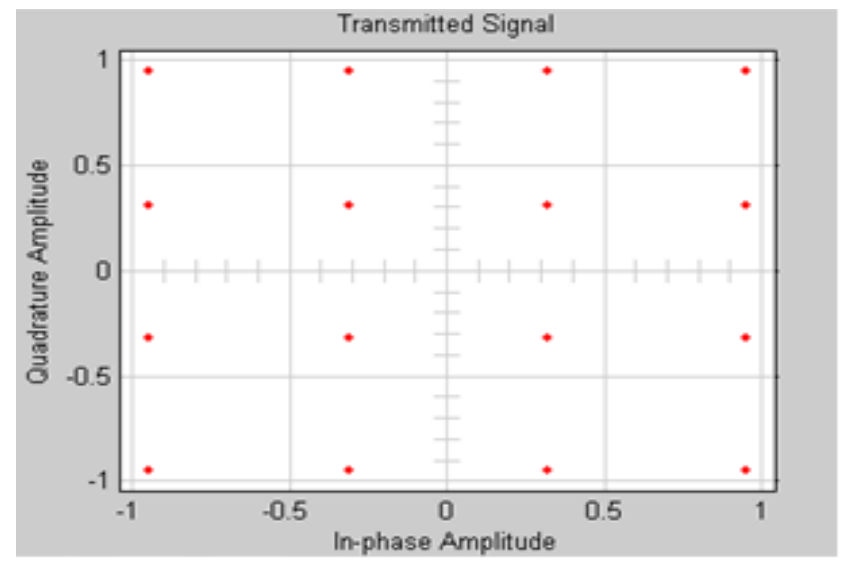

- Gambar 9. Peta konstelasi 16 QAM 
Hasil keluaran berikutnya pada titik uji 3 dalam domain waktu dan frekuensi dari subsistem ini masingmasing ditampilkan dalam Gambar 10 a dan b. Terbaca dari Gambar 10a bahwa keluaran OFDM mempunyai durasi $4 \mu$ s dengan durasi guard interval (GI) sebesar $0.8 \mu \mathrm{s}$. Hal ini menunjukkan bahwa sinyal keluaran subsistem COFDM sudah sesuai dengan spesifikasi dalam Tabel 2. Dari Gambar 10b tampak pula respons frekuensi yang hampir konstan dalam kurun frekuensi yang sesuai dengan Tabel 2.

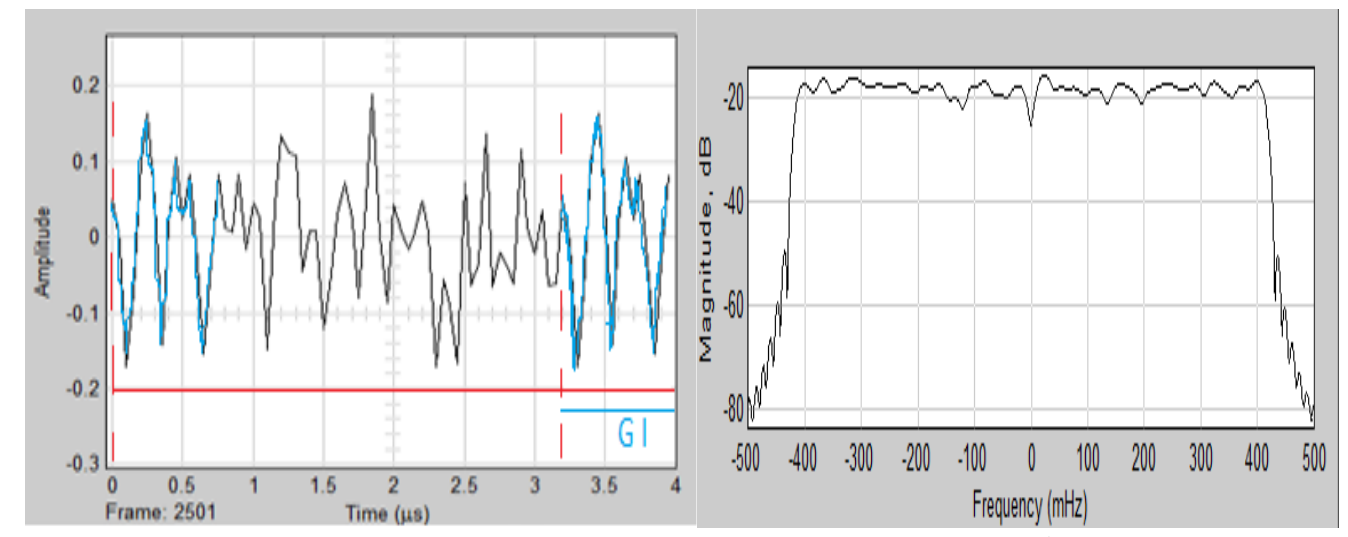

a.

b.

- Gambar 10. Sinyal keluaran subsistem COFDM dalam (a) domain waktu yang ditandai oleh durasi waktu (garis merah) dan GI (garis biru) (b) domain frekuensi

\section{Hasil Pengujian Subsistem COFDM (Penerima)}

Pengujian subsistem COFDM pada sisi penerima dilakukan dengan memberikan sinyal masukan berupa sinyal keluaran COFDM dari pemancar (Gambar 10a dan b). Subsistem ini harus memberikan keluaran berupa digit biner seperti Gambar 8. Secara berurut, hasil pengujian dari subsistem ini diperlihatkan oleh hasil rekaman pada titik uji 2' dan 1' yang ditampilkan dalam Gambar 11 dan 12. Selain itu telah dicatat pula bit error rate (BER) pada keluaran yang ditampilkan dalam Gambar 12. Gambar 11 menunjukkan bahwa sinyal keluaran dari subsistem penerima memberikan hasil yang sesuai dengan sinyal masukan pada subsistem COFDM pada sisi pemancar (Gambar 9). Namun pada Gambar 12 terlihat adanya perubahan sinyal biner terhadap sinyal masukan pada Gambar 8 , tetapi perubahan tersebut tidak menimbulkan distorsi sinyal yang berarti. Hal ini ditunjukkan oleh catatan BER sistem yang bernilai 0 .

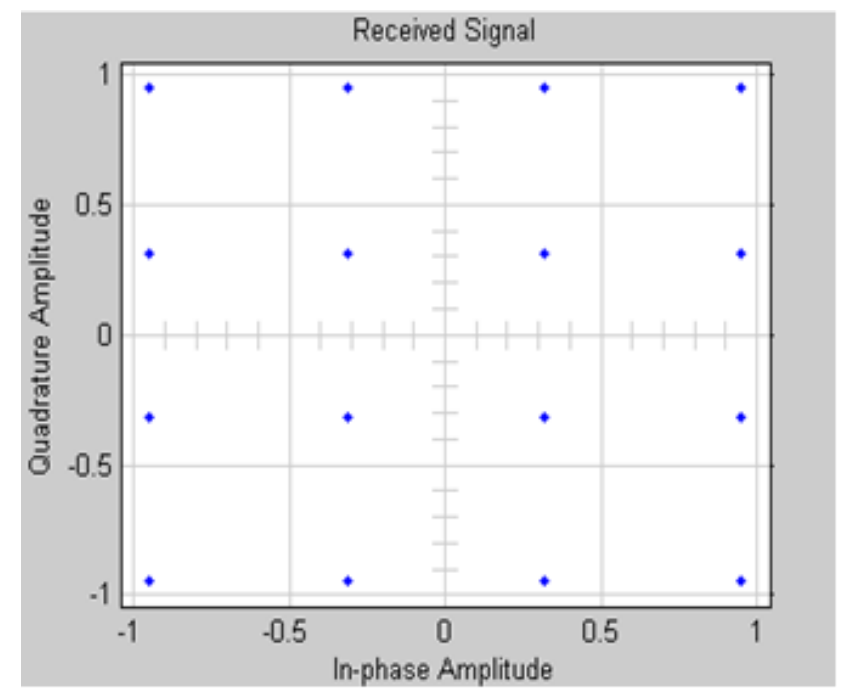

- Gambar 11. Peta konstelasi 16 QAM pada titik uji 2'. 


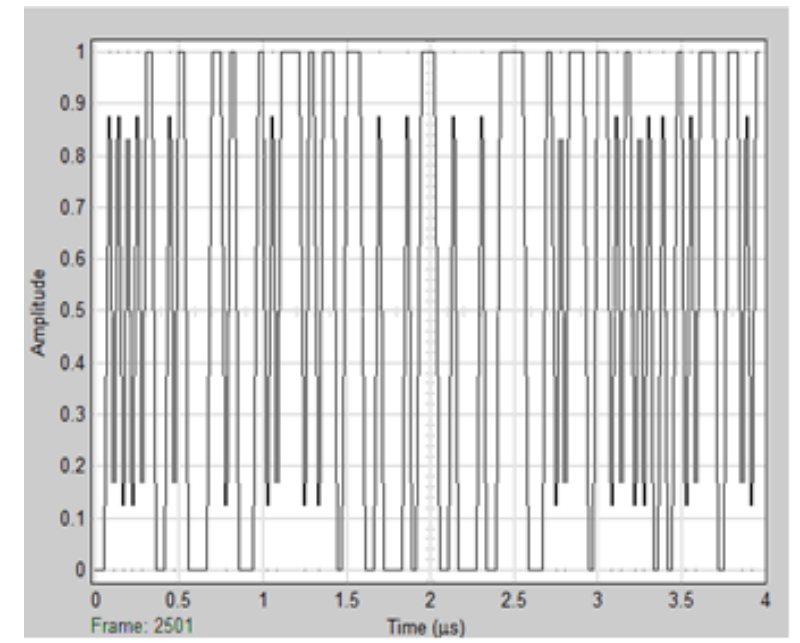

- Gambar 12. Sinyal keluaran subsistem COFDM pada titik uji 1' berupa digit biner.

\section{Hasil Pengujian Subsistem Optik}

Pengujian subsistem optik dilakukan dengan memberi sinyal masukan berupa sinyal COFDM (Gambar 4.4a) yang telah dibagi dengan hambatan listrik sebesar $2 \mathrm{Ohm}$ seperti yang terekam pada titik uji 4 (Gambar 4.7) Keluaran subsistem ini direkam pada titik uji 4' dan ditampilkan dalam Gambar 4.8 untuk jarak serat $=10$ meter.

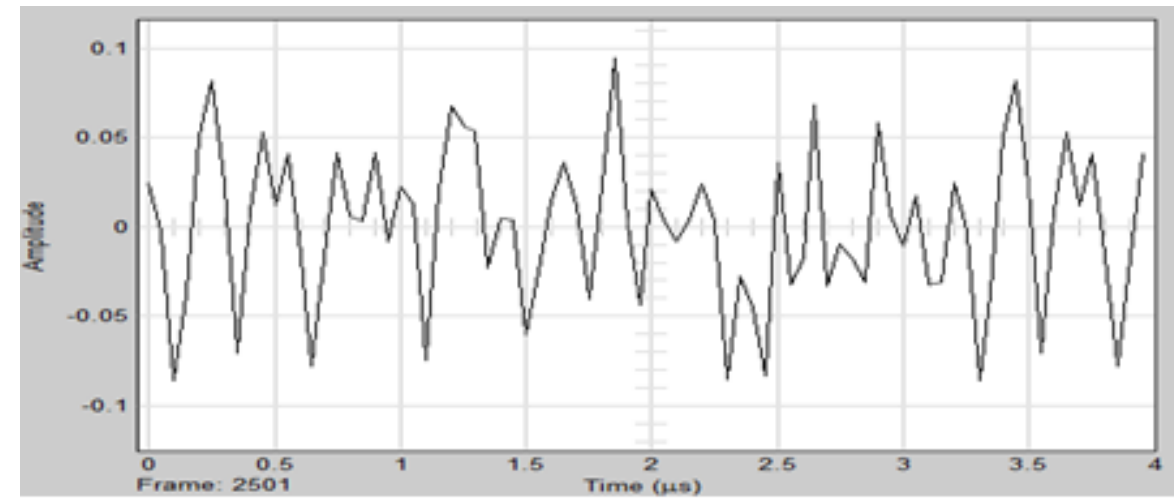

- Gambar 13. Sinyal masukan untuk subsistem optik pada titik uji 4

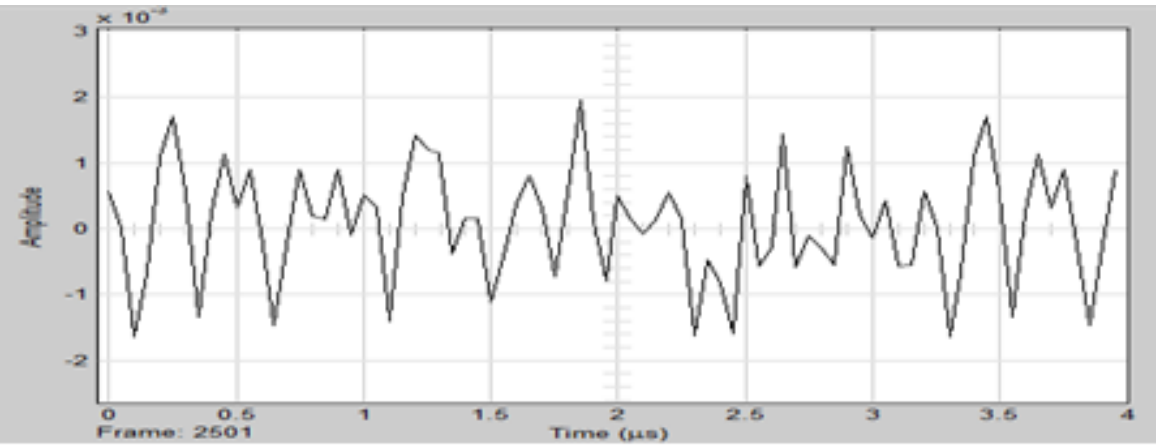

- Gambar 14. Sinyal keluaran subsistem optik pada titik uji 4'

Kedua gambar tersebut memperlihatkan kesamaan secara garis besar bentuk antara sinyal masukan dan keluaran dari subsistem optik. Tetapi secara rinci terlihat perbedaan dalam harga ampiltudenya. Jelasnya Gambar 4.8 menunjukkan bahwa harga amplitudenya mengalami peredaman dibandingkan dengan sinyal dalam Gambar 4.7. Peredaman ini terjadi akibat coupling loss dalam proses konversi elektro-optik dan opto-elektrik

\section{Hasil Pengujian Integrasi Sistem}

Hasil pengujian integrasi sistem disajikan dalam bentuk grafik variasi Bit Error Rate (BER) terhadap jarak tempuh serat optik. Pengujian ini dilakukan untuk beberapa kasus yang menggunakan jenis LD, jenis serat optik MMF beserta laju kode (code rate) dan nilai Signal to Noise Ratio (SNR) yang bervariasi. Mengingat bahwa laju data RF yang hanya berkisar sekitar $36 \mathrm{Mbit} / \mathrm{s}$, maka BER yang paling kecil hanya dapat mencapai angka $\pm 10^{-6}$. 
Hasil pengujian integrasi sistem dengan serat optik MMF OM1, laju kode 3/4 dan LD yang berbeda-beda. Dalam pengujian ini, parameter sistem yang digunakan ditunjukkan oleh Tabel 4.1.

- Tabel 5. Parameter simulasi pengujian integrasi sistem dengan serat optik MMF OM1 (Tabel 4) dan LD yang berbeda-beda

\begin{tabular}{|c|c|}
\hline Parameter & Nilai \\
\hline$\lambda$ optik & $850 \mathrm{~nm}$ \\
\hline Frekuensi Ternormalisasi (V) & 68.9 \\
\hline$\sigma_{\mathrm{c}}($ Dispersi Kromatik) & Dengan : \\
& $\bullet$ LD $1=0.0552 \mathrm{~ns}$ \\
& $\bullet$ LD $2=0.0939 \mathrm{~ns}$ \\
& $\bullet$ LD 3 $=0.1105 \mathrm{~ns}$ \\
\hline$\sigma_{\mathrm{m}}$ (Dispersi Intermodal) & $0.9350 \mathrm{~ns}$ \\
\hline Laju kode & $3 / 4$ \\
\hline Laju Data & $36 \mathrm{Mbps}$ \\
\hline SNR kanal AWGN & $15 \mathrm{~dB}$ \\
\hline
\end{tabular}

Grafik hasil pengujian ditunjukkan oleh Gambar 15

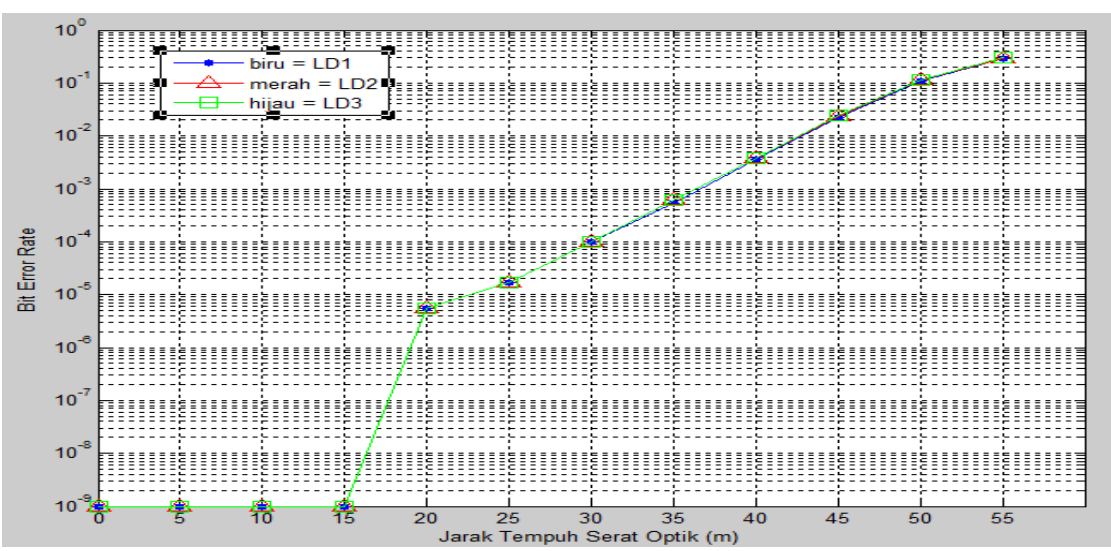

Gambar 15. Grafik BER terhadap jarak tempuh serat optik MMF OM1 dengan LD yang berbeda-beda.

Terbaca dari Gambar 15, sistem hanya dapat dipakai untuk jarak terbatas(15 meter), karena ketika jarak ini dilampaui Bit Error Rate (BER) naik dengan cepat. Hal ini diperkirakan terjadi karena dispersi intermodal yang besar.

Hasil pengujian integrasi sistem dengan serat optik MMF OM2, laju kode 3/4 dan LD yang berbeda-beda.

Dalam pengujian ini parameter sistem yang digunakan ditunjukkan oleh Tabel 6. Perubahan parameter dalam sistem ini terutama terletak pada harga $\sigma_{\mathrm{m}}$.

- Tabel 6. Parameter Simulasi Pengujian Integrasi Sistem dengan serat optik MMF OM2 (Tabel 4) dan LD yang berbeda-beda

\begin{tabular}{|c|c|}
\hline Parameter & Nilai \\
\hline$\lambda$ optik & $850 \mathrm{~nm}$ \\
\hline Frekuensi Ternormalisasi (V) & 38.8 \\
\hline$\sigma_{\mathrm{c}}$ (Dispersi Kromatik) & Dengan : \\
& $\bullet$ LD $1=0.0480 \mathrm{~ns}$ \\
& $\bullet$ LD $2=0.0816 \mathrm{~ns}$ \\
& LD 3 $=0.0960 \mathrm{~ns}$ \\
\hline$\sigma_{\mathrm{m}}($ Dispersi Intermodal $)$ & $0.3740 \mathrm{~ns}$ \\
\hline Laju kode & $3 / 4$ \\
\hline Laju Data & $36 \mathrm{Mbps}$ \\
\hline
\end{tabular}




\begin{tabular}{|c|c|}
\hline SNR kanal AWGN & $15 \mathrm{~dB}$ \\
\hline
\end{tabular}

Grafik hasil pengujian ditampilkan dalam Gambar 16.

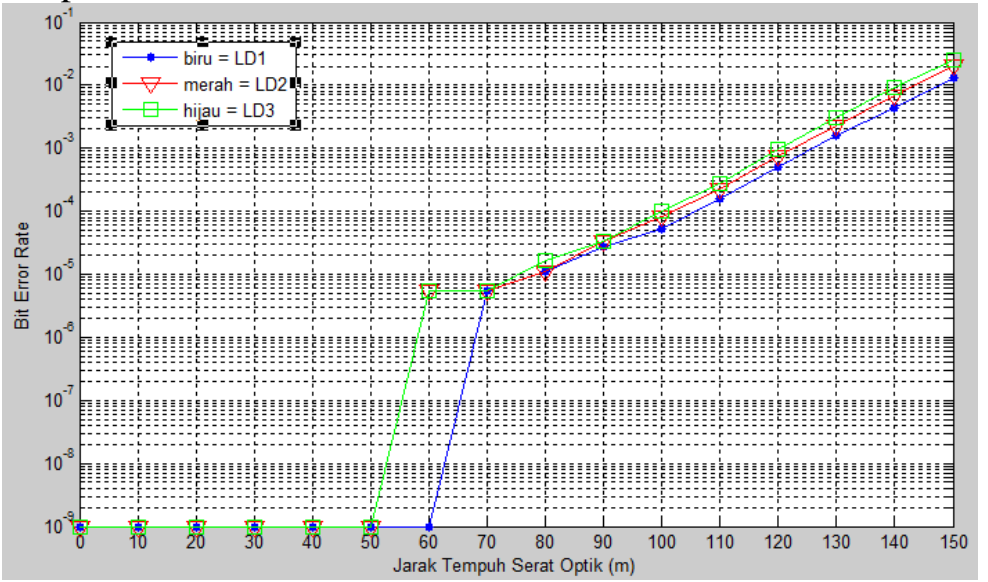

Gambar 16. Grafik BER terhadap Jarak Tempuh Serat Optik MMF OM2 dengan LD yang berbeda-beda Jelas dari gambar di atas bahwa sistem ini sanggup mempertahankan BER pada jarak yang lebih lebar dibandingkan sistem dengan serat optik MMF OM1, laju kode 3/4 dan LD yang berbeda-beda (Tabel 5). Dari Gambar 16 juga terlihat bahwa untuk LD dengan lebar spektrum yang lebih lebar akan menghasilkan dispersi kromatik yang lebih besar.

\section{Hasil pengujian integrasi sistem dengan serat optik MMF OM3, laju kode 3/4 dan LD yang berbeda-beda.}

Dalam pengujian ini, parameter sistem yang digunakan ditunjukkan oleh Tabel 7. Perubahan utama dari sistem ini terdapat pada harga dispersi intermodal $\left(\sigma_{\mathrm{m}}\right)$.

- Tabel 7. Parameter Simulasi Pengujian Integrasi Sistem dengan serat optik MMF OM3 (Tabel 4) dan LD yang berbeda-beda

\begin{tabular}{|c|c|}
\hline Parameter & Nilai \\
\hline$\lambda$ optik & $850 \mathrm{~nm}$ \\
\hline Frekuensi Ternormalisasi (V) & 38.8 \\
\hline$\sigma_{\mathrm{c}}($ Dispersi Kromatik) & Dengan : \\
& $\bullet$ LD $1=0.0480 \mathrm{~ns}$ \\
& $\bullet$ LD $2=0.0816 \mathrm{~ns}$ \\
& $\bullet$ LD 3 $=0.0960 \mathrm{~ns}$ \\
\hline$\sigma_{\mathrm{m}}$ (Dispersi Intermodal) & $0.1274 \mathrm{~ns}$ \\
\hline Laju kode & $3 / 4$ \\
\hline Laju Data & $36 \mathrm{Mbps}$ \\
\hline SNR kanal AWGN & $15 \mathrm{~dB}$ \\
\hline
\end{tabular}

Grafik hasil pengujian ditampilkan dalam Gambar 17 .

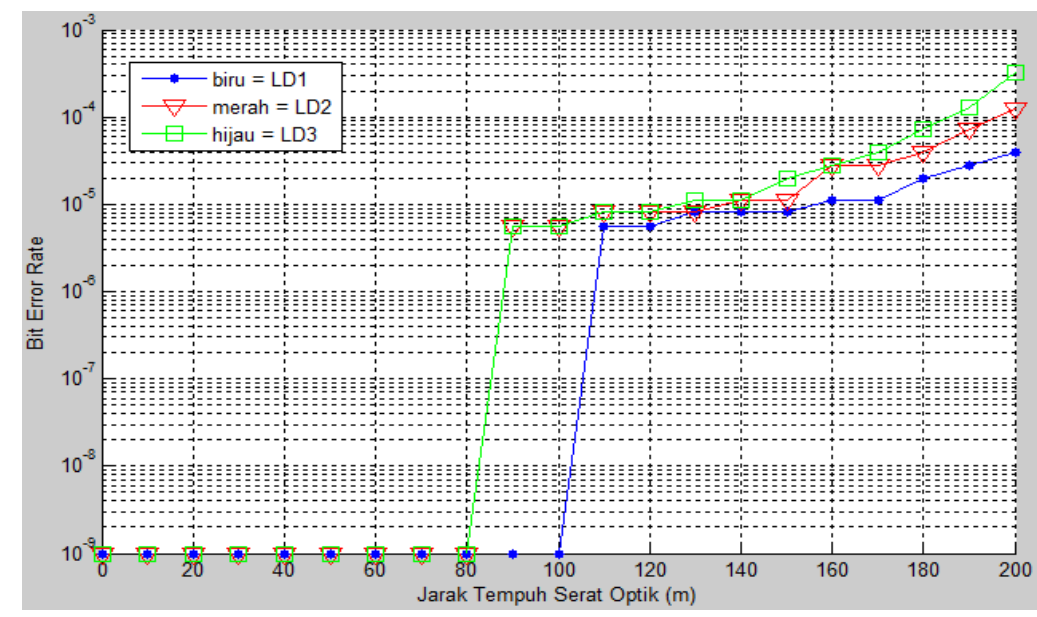

Gambar 17. Grafik BER terhadap Jarak Tempuh Serat Optik MMF OM3 dengan LD yang berbeda-beda 
Gambar 17 menunjukkan bahwa sistem ini mampu mempertahankan BER pada jarak tempuh yang lebih jauh dibandingkan sistem pada pasal 1 dan 2. Dalam kasus ini, degradasi sinyal tampak terjadi dengan cepat dengan penambahan jarak tempuh dibandingkan kasus-kasus sebelumnya.

\section{Analisis hasil pengujian pasal 1, 2, dan 3}

Dari hasil ketiga pengujian dapat ditunjukkan bahwa jarak tempuh yang dapat mempertahankan kualitas sinyal (BER) sangat bergantung pada dispersi kromatik dan dipersi intermodal yang masing-masing bergantung pada karakteristik LD khususnya lebar spektral LD $(\Delta \lambda)$ dan karakteristik serat. Hal ini berarti, untuk mencapai jangkauan jarak tempuh yang besar, efek dispersi dari kedua sumber tersebut harus diperkecil. Efek dispersi kromatik sangat bergantung pada $\Delta \lambda$, oleh karena itu efek ini dapat diperkecil dengan memilih LD yang mempunyai kemurnian spektral tinggi. Sedangkan untuk dispersi intermodal dapat dihilangkan dengan menggunakan serat optik bermodus tunggal (SMF).

Dari hasil tersebut, jarak tempuh yang paling besar dapat dicapai dengan menggunakan LD1 $(\Delta \lambda=0.5$ $\mathrm{nm})$ dan serat optik MMF OM3.

\section{Hasil pengujian integrasi sistem dengan serat optik MMF OM3, LD1 dan laju kode yang berbeda-beda.}

Parameter yang dipakai dalam pengujian ini ditunjukkan oleh Tabel 8.

- Tabel 8. Parameter Simulasi Pengujian Integrasi Sistem dengan Serat Optik MMF OM3 (Tabel 3.1), LD1 dan laju kode yang berbeda-beda

\begin{tabular}{|c|c|}
\hline Parameter & Nilai \\
\hline$\lambda$ optik & $850 \mathrm{~nm}$ \\
\hline LD & LD 1 \\
\hline$\sigma_{\mathrm{c}}($ Dispersi Kromatik $)$ & MMF OM 3 $=0.0480 \mathrm{~ns}$ \\
\hline$\sigma_{\mathrm{m}}($ Dispersi Intermodal $)$ & OM $3=0.1247 \mathrm{~ns}$ \\
& $1 / 2,2 / 3,3 / 4,5 / 6$ \\
\hline Laju kode & $15 \mathrm{~dB}$ \\
\hline SNR kanal AWGN & \\
\hline
\end{tabular}

Grafik hasil simulasi ditampilkan dalam Gambar 18.

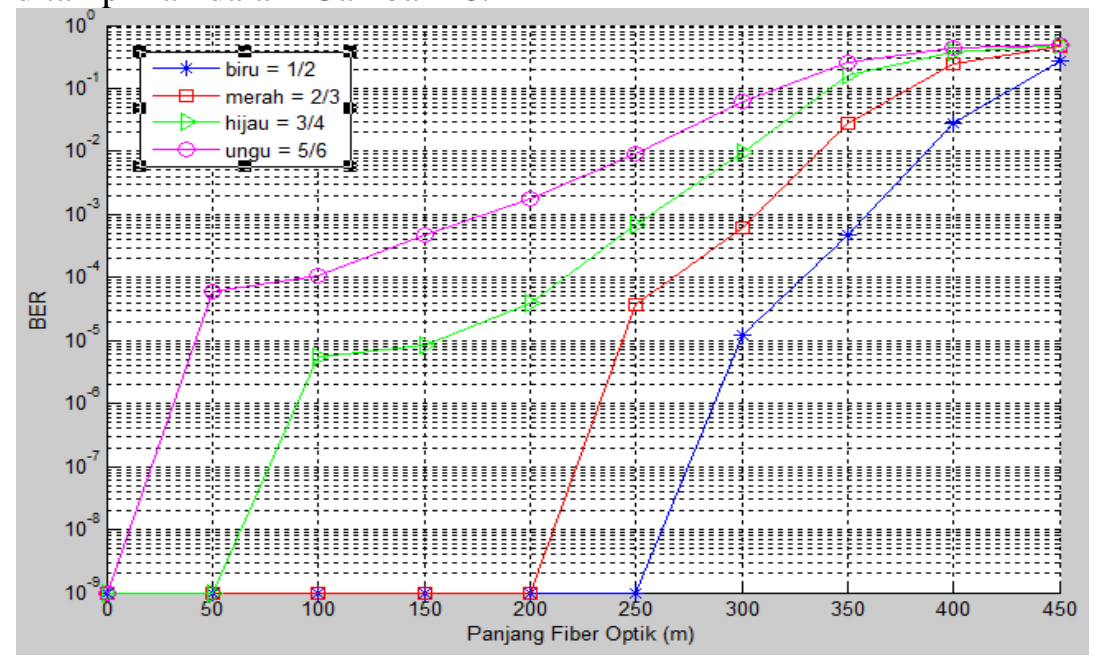

Gambar 18. Grafik BER terhadap Jarak Tempuh Serat Optik MMF OM3 dengan laju kode yang berbeda-beda

Gambar 18 terlihat bahwa untuk laju kode 1/2, BER sistem dapat lebih terjaga. Hal ini disebabkan karena proteksi sinyal (redundant bit) yang diberikan oleh laju kode $1 / 2$ lebih besar dibanding laju kode lainnya. Namun sebagai akibatnya lebar pita akan menjadi lebih kecil.

6. Hasil pengujian integrasi sistem dengan serat optik MMF OM3, LD1, laju kode 3/4, dan harga Signal to Noise Ratio (SNR) yang berbeda-beda.

Grafik hasil pengujian ditampilkan dalam Gambar 19. 


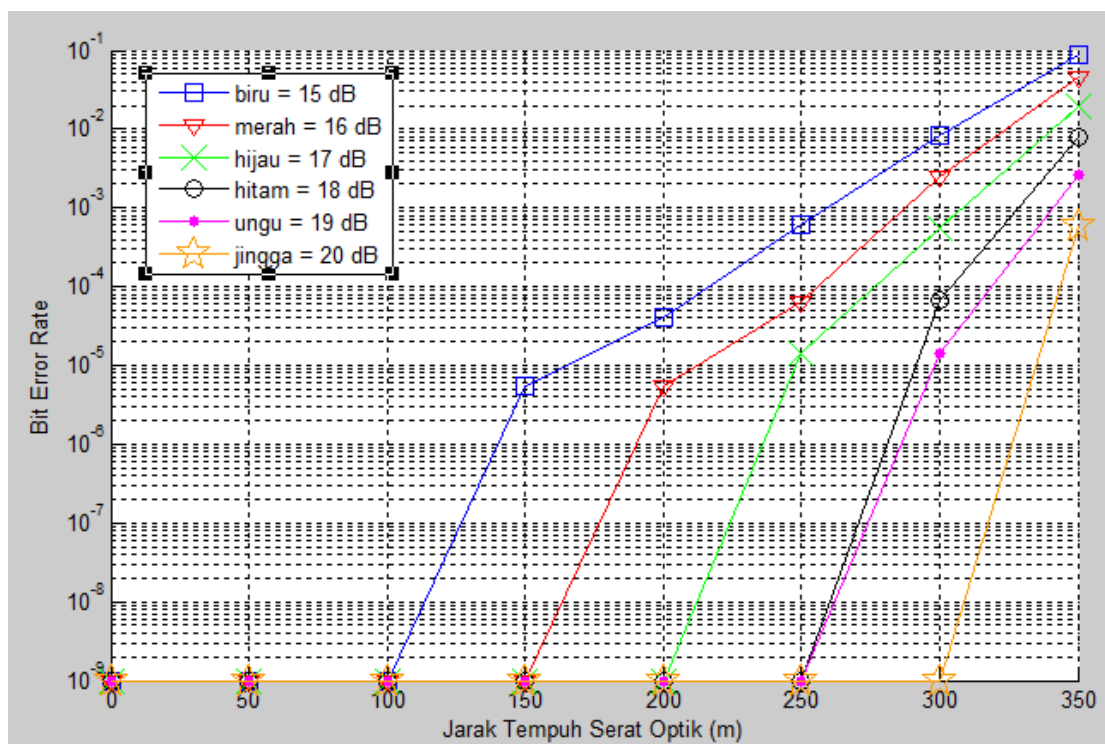

Gambar 19. Grafik BER terhadap jarak tempuh serat optik MMF OM3 dengan harga SNR yang berbeda-beda

Hasil pengujian di atas menunjukkan bahwa semakin besar harga SNR yang digunakan, maka performa sistem semakin baik. Hal ini disebabkan karena semakin besar harga SNR yang digunakan, maka gangguan yang terjadi menjadi lebih kecil.

\section{KESIMPULAN}

Dari hasil pengujian yang dilakukan, didapat hasil sesuai dengan spesifikasi yang dirancang. Kesimpulan yang dapat diambil secara umum dari simulasi yang telah dilakukan dalam tugas akhir menunjukkan bahwa kualitas sistem RoF ditentukan terutama oleh kualitas dari performa subsistem optiknya.

Selanjutnya, secara spesifik dapat disimpulkan pula faktor-faktor khusus yang berperan dalam menentukan kinerja sistem RoF yaitu :

- Dispersi intermodal sangat berpengaruh dalam sistem komunikasi COFDM-RoF. Cara paling efektif untuk menghilangkan efek dispersi intermodal adalah menggunakan SMF. Namun pemilihan ini harus ditentukan atas dasar kebutuhan jarak tempuh yang diperlukan sesuai dengan pertimbangan cost effectiveness.

- Penggunaan laju kode yang lebih kecil memperbaiki kinerja sistem secara keseluruhan. Namun perbaikan ini akan mengurangi lebar pita transmisi sistem. Oleh karena itu, pemilihan laju kode yang digunakan harus didasarkan pada optimalisasi sistem secara keseluruhan.

- Hasil pengujian integrasi sistem terbaik, dengan serat optik MMF OM3, laju kode 3/4, LD1, dan harga SNR $20 \mathrm{~dB}$ memiliki jarak tempuh maksimum sebesar 300 meter. Dengan kata lain, sistem ini layak untuk digunakan pada komunikasi LAN dalam gedung.

- Dalam sistem ini secara keseluruhan, disamping hal-hal di atas, coupling loss yang terjadi antara subsistem radio-optik ikut mempengaruhi performa sistem, tetapi tidak diselidiki lebih lanjut dalam tugas akhir ini.

\section{SARAN}

Untuk kedepannya, diharapkan simulasi yang dilakukan dapat menggunakan masukan dan keluaran berupa gambar atau suara. Dalam simulasi ini derau yang terjadi pada LD dan PD serta rugi-rugi seperti coupling loss dan splicing loss diabaikan. Oleh karena itu, untuk selanjutnya diharapkan faktor-faktor penyebab derau dan rugi-rugi tersebut dapat diperhitungkan sehingga simulasi yang dilakukan menjadi lebih akurat. Selain itu, diharapkan agar simulasi ini selanjutnya dapat direalisasikan ke dalam bentuk perangkat keras (hardware).

\section{DAFTAR PUSTAKA}

[1] M. Shikha, N. Kumar, COFDM for Radio over Multimode Fiber: a Review, IJCA special issues on IP Multimedia Communications, pp. 22-28, 2011.

[2] J.M.P. Rosas, "Optical Orthogonal Frequency Division Systems with Direct Detection Receivers", Universitat Politecnicade Catalunya, 2013.

[3] Technologies \& Services of Digital Broadcasting (9): Modulation Systems (part2), Autumn 2003. https://www.nhk.or.jp/strl/publica/bt/en/le0016.pdf.

[4] M. Viswanathan, Simulation of Digital Communication Systems Using MATLAB, 2nd ed. Maturanathan Viswanathan at Gaussianwaves, 2013. 
[\#] S. Botachi, Multi-gigabit Transmission Over Multimode Optical Fibre: Theory \& Design Methods for 10GbE Systems, West Sussex: John Wiley \& Sons Ltd, 2006. 